\title{
The Impact of the Capital Adequacy Ratio, Non- Performing Loan Against to Return on Equity (Case Study Private Bank in Indonesia)
}

\author{
Pirmanta Sebayang* \\ Accounting Courses-University Tama Jagakarsa, Letjen T.B. Simatupang No. 152, \\ Jakarta 12530, Indonesia.
}

\begin{abstract}
Banks in Indonesia always pay attention to the Capital Adequacy Ratio (CAR) to obtain adequate bank performance, while also paying attention to Non-Performing Loan (NPL). Banks want a high Return on Equity (ROE) to be able to be declared healthy and the bank's performance is also very good. Banking companies always make financial reports related to the banking performance. This study has two objectives namely, first to examine the effect of Capital Adequacy Ratio (CAR) on Return on Equity (ROE). Second, to examine the effect of Non-Performing Loans (NPLs) on Return on Equity (ROE) in foreign private banks that have been determined by the government. This study uses multiple regression analysis techniques using a sample of 20 banks. The test results show that there is an increase in capital Adequacy Ratio (CAR) that will be able to increase the Return on Equity (ROE) of foreign private banks in Indonesia. Increased Non-Performing Loans (NPLs) can have a positive effect and increase Return on Equity (ROE). Simultaneous tests carried out obtained the variable Adequacy Ratio (CAR) and Return on Equity (ROE) to have a joint impact on the Return on Equity (ROE) of private banks.
\end{abstract}

Keywords: Health of banking, liabilities, private bank, profitability.

\section{Introduction}

Banking experts and global economic agreed to build an architecture in the banking industry that later became the guidelines, reference for the banking industry in the world. It is in line with the Basel Accor and BIS (Bank of International Settlement). Leading indicators in anticipation of the emergence of banking risk then the quality of the asset becomes the main focus in the discussion of the minimization of the risk of the bank as well as the efficiency in which global competition in the context of a highly competitive industry banking on the stress to perform efficiency. The national banking is facing the era of globalization is that of some indicators about the health of the bank's assets quality, banks cash flow and efficiency turns out to provide sufficient influence the health of banking [1] and although other indicators cannot be denied [2].

The existence of banking health indicator shifts much influenced by a variety of factors, the behavior of bank health is determined by internal factors, namely monetary policy and

\footnotetext{
*Corresponding author: firmantabayangndu@gmail.com
} 
fiscal policy, which leads to more aspects of efficiency [3]. While external factors are the harmonious interconnected system of banking that leads to the capital factor and efficiency, that globalization of banking would be more use of the approach capital and asset quality [4]. Basically from the background, then the author can formulate the problem as follows: first if the Capital Adequacy Ratio (CAR) of influential partially against the Return On Equity (ROE)? Second does Non-Performing Loan (NPL) have impact and increase the value of Return On Equity (ROE)? Third, the Capital Adequacy Ratio (CAR) and NonPerforming Loan (NPL) impact jointly and increase value of Return On Equity (ROE)?

\section{Grounding conceptual}

\subsection{Banks}

Bank are financial institutions that its main activity is to gather funds from the community and channel it back those funds to the community and provide services to other Banks [5]. Understanding Bank according to the law - Law No. 10 year RI 1998 November 18, 1998 on banking is: a business entity that funds from the public in the form of savings and channel it to the community in the form of credit and or bent other UK in order to improve the living standard of the people's lot. Intermediary bank Surplus Spending Unit (SSU) and Deficit Spending Unit (DSU), the bank's principal business is based on the four principal things, namely: i). Denomination Divisibility, meaning banks gather funds from SSU, each value is relatively small, but overall the numbers are big banks; thus will be able to meet the demand for DSU that requires these funds in the form of credit. ii). Maturity Flexibility, meaning the bank in lumping the Fund, organizes the deposit forms vary time frame and funding, such as fixed deposits, savings book. iii). Liquidity Transformation, meaning that the funds saved by the savers (SSU) to the bank generally illiquid. Therefore, SSU can quickly dilute following the form of his savings. iv). Risk Diversification, meaning banks in channeling credit to many parties or the debtor and economic sectors so that a wide range of risks faced by the bank by way of a credit spread is getting smaller [6].

\subsection{Financial ratios}

Financial ratio is a comparison between the two elements of the financial statements that show an indicator of financial health at a particular time [7]. Ratios as a mathematical relationship disclosure of an amount by the number of other or comparison between the one post with a post to another. Liquidity ratio analysis is the analysis of the bank's ability to meet short-term obligations or liability which is due [8]. Analysis of the ratio of a bank: the Cash Reserve Requirement Ratio, or the liquidity of the mandatory minimum. Loan to Deposit Ratio, Loan to Total assets, and the ratio of Net Liabilities of Call money.

The higher the liquidity of a banking will further lower liquidity risk faced by banking because the banks can meet all obligations that have fallen due or paid for the short-term debt with tools like the acquisition of a liquid, the high banking will further improve the trust of customers, communities, and Governments so that the funds collected from the community will be getting larger every period. Analysis earning ratios are as a tool for measuring business efficiency bank and the the value of profitability levels objective by the bank in question. The higher the ratio of earning ratios, a bank can be said the bank is in a healthy condition in running its operation so that the risk of bankruptcy facing banks is getting smaller.

Analysis of the solvency ratio are used to measure performance a bank's ability to meet obligations. This ratio is also used to know the comparison between the number of funds obtained from the various debt as well as the sources of outside capital alone with the 
magnitude of the planting of those funds on various types of the Akiva bank-owned. The quality of earning assets is the ratio or ratios between the productive assets allowance established and productive assets allowance that must be established.

\subsection{Capital Adequacy Ratio (CAR)}

Capital Adequacy Ratio is a capital comparative value that shows the ability of a bank to provide funds for the needs of the banking business development and to accommodate and anticipate if possible risk arising from bank. The bank takes a greater risk then it must include greater capital to be able to anticipate risks that will occur [9]. Calculation of Capital Adequacy Ratio is based on the principle that any planting containing the risk should be provided a specific percentage of the amount of capital against the amount of cultivation occurring. In line with the standards established Bank for International Settlement (BIS), bank Indonesia requires that every bank provides a minimum capital of 8 $\%$ of the risk-weighted assets (RWA) [ 10].

The formulation of CAR in the bank are :

$$
\begin{gathered}
\text { Capital Bank } \\
\text { Risk-Weighted Assets }
\end{gathered}
$$

\subsection{Non-Performing Loan}

The regulation of bank Indonesia No. 5-year 2003, the risk is the potential for the occurrence of an event (event) that can cause any harm. Because of the environmental situation of the external and internal banking experience, the rapid development of the Bank Indonesia regulation, one of the bank's business risk is a credit risk, which is defenition are: the risks arising as a result of the failure of the counterparty meet the obligation. Credit Risk is the risk faced by the bank due to channel funds in the form of loans to the public. Due to various reasons, the debtor might be not meet its payments to banks such as the loan principal, interest payments, and others. It does not satisfy the obligation of the customer to the bank led the bank to suffer losses with no receipt of the Penniman that had previously been estimated.

Mathematically the NPL can be formulated as follows [11]:

$$
\begin{gathered}
\text { The amount of bad debt } \\
\text { Total credit }
\end{gathered}
$$

\subsection{Return On Equity (ROE)}

Return on Equity (ROE) is a measure of bank performance, where the higher the value of ROE for a bank, the better the bank's performance. ROE a bank performance measure used for the net profit generated by a bank and shared with the equity holders of the company's shares and generally calculated based on the value of banking accounting. Return on Equity (ROE) is the ratio of the net against ordinary equity measure the return on investment of ordinary shareholders. Return on Equity (ROE) ratio is used to examine the extent to which a company uses resources that belong to able to deliver a return on equity. From the value of ROE, according to some experts, it can be concluded that ROE was the return on common stock equity used to measure the level of profit that results from investments of shareholders.

The Return on Equity is a comparison between the net profit of the bank with its capital. The formula calculates ROE: 


$$
\text { ROE }=\text { - -------------------------- x } 100 \%
$$

\section{Framework research}

This research uses Return On Equity (ROE) as the dependent variable. Moreover, use other financial ratios ratio-like CAR and the NPL as a variable, independent manner. Assessment of the performance of the bank is very important for a banking company. This assessment is very needed by many parties in addition to the Government and is also important for customers and shareholders. Analysis of financial ratios the bank is one of the tools or the most common way used in analyzing the financial statements. These analyses can illustrate how the performance of a bank. The profit growth continued to increase from year to year would provide positive information to the company. Thus, the framework of thought influences several financial ratios banking (CAR and NPL) against ROE private Bank in Indonesia can be seen in the Figure below.

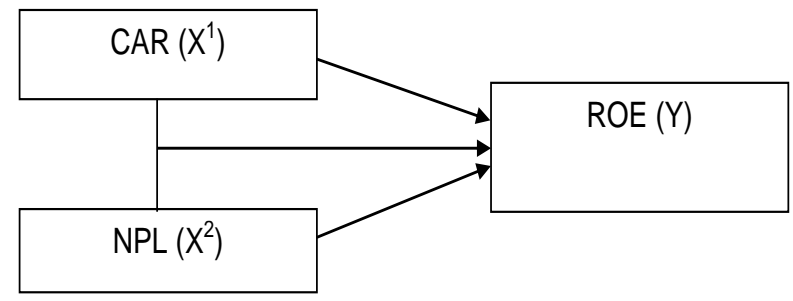

Fig. 1. Model of research.

\section{The hypothesis}

From the explanation above, a hypothesis can be obtained as follows: the first being that there is a positive impact and an increase in the value of the Capital Adequacy Ratio (CAR) on Return On Equity (ROE). Second, it is suspected that there is a positive impact and gives an increase in the value of Non-Performing Loans (NPL) on Return On Equity (ROE). The third hypothesis, namely it is suspected that there is a positive impact and gives an increase in the value of Non-Performing Loans (NPL) and Capital Adequacy Ratio (CAR) on Return On Equity (ROE)).

\section{Research methodology}

To get the necessary data in this study, the authors visited the Bank Indonesia website with URL address, i.e. www.bi.go.id. While the time research was done during 3 mo IE January up to March 2017. The population used in this research is the entire private Bank foreign exchange listed in the directory of Bank Indonesia. That is as many as 43 banks. Research samples were taken in purposive sampling namely sample was drawn from the population of a certain number of issuers by using specific criteria or considerations.

Criteria for the selection of the samples will be examined in this study are as follows: i). the private Bank foreign exchange that has been going public at the Jakarta Stock Exchange (JSX). ii). Foreign Exchange private Bank serving the financial statements and ratio - the ratio is needed in this study, i.e. for five consecutive years from 31 December 2011 up to 31 December 2015 and has been submitted to Bank Indonesia. Based on the 
selection criteria samples above, the number of samples obtained as many as 20 foreign exchange Bank.

The research of using multiple regression analysis models with the smallest quadratic equations or ordinary least square (OLS) to analyze the influence of the CAR and the NPL against ROE, with basic models as follows:

$$
\mathrm{Y}=\alpha+\beta 2 \times 2+\beta 1 \mathrm{X} 1+\mathrm{e}
$$

Description: Y: ROE $\alpha: \beta$ 1, $\beta$ Constant 2: regression coefficients X 1: x 2: CAR, NPL e: standard error.

Classical assumptions in the study include the test of normality, test multicollinearity, heteroskedasticity test, and a test of autocorrelation. The coefficient of determination function to see the overall independent variables the dependent variable can explain. When the number of coefficients of determination of getting closer to 1, then the CAR and NPL impact the dependent variables are ROE, which means independent variables provide almost all of the information needed to predict variation in the dependent variable. While the value of the coefficient of determination of small means, the ability of independent variables in explaining the variation in the dependent variable is limited [12].

Statistical tests $t$ used to test the influence of each independent variable used in partial. As for whose hypotheses are formulated are: $\mathrm{H}_{0}$ : bi $=0$ means that is no have impact the significant of the one independent variable to dependent variable. $\mathrm{H}_{\mathrm{a}}$ : bi $<0$ or $\mathrm{Ha}>0$ means that have a significant impact of the dependent variable against the independent variable.

Value t-statistic can be searched with the formula: If t-female > t-table, then HO is rejected, and the $\mathrm{Ha}$ is received. If $\mathrm{t}$-calculate the $\mathrm{t}$-table <, then $\mathrm{HO}$ is accepted, and $\mathrm{Ha}$ was rejected.

\section{Research results}

Capital Adequacy Ratio (CAR) of influential partially against the Return On Equity (ROE): the first hypothesis is suggesting that the Capital Adequacy Ratio (CAR) and NonPerforming Loan (NPL) influential partially against the Return On Equity (ROE). Of research results obtained coefficient CAR of 3.034 regression significance value of 0.003 . This value is significant because of 0.003 smaller than 0.05 . The increase in variable CAR affect ROE with so it can be concluded that the CAR is a significant effect against ROE. Then the hypothesis stating the Capital Adequacy Ratio (CAR) of influential partially against the Return On Equity (ROE) was received.

Non-Performing Loan (NPL) does not affect partially against the Return On Equity (ROE) of research results obtained, the value significance of NPL of the regression coefficient of $0.650-0.455$. Judging from their significance levels shows that the result is not significant because of the value of the NPL-0.650 significance greater than 0.005 . In this case, the influence of the NPL against ROE could not be interpreted. Then it can be inferred that the NPL does not affect the Return On Equity (ROE). The increase or decrease in the ratio of NPL does not have an impact on Return On Equity (ROE). So the hypothesis stating that Non-Performing Loan (NPL) partial effect against the Return On Equity (ROE) is not acceptable.

Bad credit quality will increase risk, especially when granting credit is done by not using the principle of prudence and expansion in granting credit the less restrained so that banks will bear greater risk anyway. The risk in the form of credit repayment difficulties by the debtor when the amount is big enough can affect the performance of banking. There 
are the problematic credits causing credit channeled many do not deliver results. The increase or decrease in the ratio of NPL does not have an impact on Return On Equity (ROE).

Capital Adequacy Ratio (CAR) and Non-Performing Loan (NPL) influential simultaneously against the Return On Equity (ROE): The third hypothesis states that the Capital Adequacy Ratio (CAR) and Non-Performing Loan (NPL) influential simultaneously against the Return On Equity (ROE). Based on the test, F may note that simultaneous independent variables have significant effects on the independent variable. This is evidenced by the $\mathrm{F}$ value count of $5.626 \%$ with the significance of 0.00 . Then inferred that the independent variable (CAR and NPL) influential simultaneously (together) against the dependent variable is Return On Equity (ROE).

\section{Conclusion}

Based on research and analysis that has been done with regard to the conclusions of this research are as follows: first, Calculation based on partially (t-test) shows that the variable Capital Adequacy Ratio (CAR) of significant effect against Return On Equity (ROE). Second, based on the calculation of partially ( $t$-test) shows that the Non-Performing Loan (NPL) does not affect a significant Return On Equity (ROE). Based on the results of test calculations $\mathrm{f}$ indicates that the variable Capital Adequacy Ratio (CAR) and NonPerforming Loan (NPL), the simultaneous effect on Return On Equity (ROE). The management of the company must be able to meet the standards of the magnitude of the CAR that should be owned by the Bank in accordance with the provisions of Bank Indonesia of $8 \%$. In an attempt to improve the company's ROE should be able to maintain the level of investment that will improve the performance of the Bank. Looking at the variables NPL management expected to suppress the magnitude of this ratio. The increase in this ratio relates negatively to ROE; any rise in the NPL will lower ROE. Due to the increase in NPL reflects the number of troubled banks received the credit due to poor credit quality.

\section{References}

1. G. Danisman, Commerce and Management, 6,4:59-71(2018). http://ijecm.co.uk/wpcontent/uploads/2018/04/645.pdf

2. N. Laoli, Menko Darmin Nasution sebut lima kebijakan ini jadi pilar transformasi ekonomi [Coordinating Minister Darmin Nasution called these five policies the pillars of economic transformation] [Online] from:

https://nasional.kontan.co.id/news/menko-darmin-nasution-sebut-lima-kebijakan-inijadi-pilar-transformasi-ekonomi (2019) [Accessed on 11 April 2019] [in Bahasa Indonesia].

3. C.A. Hartwell, Explorations in Economic History, 68:37-70(2018). https://www.sciencedirect.com/science/article/pii/S0014498317301754

4. H. Bytröm, Global Finance Journal, 34:88-99(2017). https://www.sciencedirect.com/science/article/pii/S1044028316301119

5. A.M. Agoba, J. Abor, K.A. Osei, J. Sa-Aadu, Central Bank Review, 17,4:131146(2017). https://www.sciencedirect.com/science/article/pii/S1303070117300550

6. M.S.P. Hasibuan, Dasar-dasar perbankan. [Banking Fundamental]. Jakarta: PT. Grafindo (2008). [in Bahasa Indonesia]. https://www.belbuk.com/dasardasarperbankan-p-250.html 
7. N. Nuryani, T.T. Heng, N. Juliesta, Procedia - Social and Behavioral Sciences, 221:268-276(2015).

https://www.sciencedirect.com/science/article/pii/S1877042815053744

8. A.M. Dahir, F. Mahat, N.H.A. Razak, A.N. Bany-Ariffin, Borsa Istanbul Review, 19,2:139-148(2019).

https://www.sciencedirect.com/science/article/pii/S2214845018301844

9. M. Matejaš́ák, Procedia Economics and Finance, 25:256-263(2015). https://www.sciencedirect.com/science/article/pii/S2212567115007364

10. BI. Surat Edaran Direksi Bank Indonesia Nomor 26/5/BPPP Tahun 1993. [Circular of Directors of Bank Indonesia Number 26/5 / BPPP 1993]. [Online] from https://www.hukumonline.com/pusatdata/detail/lt4b25c7302184b/node/899/sedireksi-bank-indonesia-no-26_5_bppp-tahun-1993-tatacara-penilaian-tingkatkesehatan-bank-umum (1993). [Accessed on 11 April 2019].

11. Kasmir, Bank dan Lembaga Keungan Lainnya. [Banks and other financial institutions]. Jakarta: Raja Grafindo Persada. (2011) [In Bahasa Indonesia]. https://openlibrary.telkomuniversity.ac.id/pustaka/15268/bank-dan-lembagakeuangan-lainnya-edisi-revisi.html

12. Cooper, D.R. and Schindler, P.S., Business Research Methods, Twelfth edition, USA: McGraw-Hill (2013). https://www.academia.edu/34618043/Business_Research_Methods_12th_Edition_Donald_R_Cooper 